\title{
The marketing of tourism services using the internet: A resource-based view
}

\author{
R. Elliott* \\ Department of Business Management, University of Fort Hare, \\ PO Box 7426, East London 5201, Republic of South Africa \\ RElliott@ufh.ac.za \\ C. Boshoff \\ Department of Business Management, University of Stellenbosch, \\ Private Bag X1, Stellenbosch 7600, Republic of South Africa \\ cboshoff@sun.ac.za
}

Received June 2009

\begin{abstract}
Taking a resource-based view of the business, this study attempts to identify the non-technology resources driving the successful use of the Internet for marketing tourism services. If these complementary resources can be identified, they can be used to leverage the use of the Internet for marketing, which in turn will contribute to a sustainable competitive advantage for small tourism businesses.
\end{abstract}

\begin{abstract}
Hypotheses are developed and then tested by making use of a large-scale empirical study. The results indicate that a network of effective alliances, the existence of a product champion in the business, and appreciation by the ownermanager of the broader business implications surrounding the implementation of the Internet for marketing, are important to the successful use of the Internet for the marketing of tourism services.
\end{abstract}

\begin{abstract}
The study makes a contribution to the literature by identifying and measuring the drivers of Internet marketing success, as well as by establishing how resource-based theory provides a valuable approach to consideration of how these factors can be managed.
\end{abstract}

*To whom all correspondence should be addressed.

\section{Introduction}

The potential benefits of using the Internet as a marketing tool in the tourism industry have been well documented (Gretzel, Yuan \& Fesenmaier, 2000; Hoof, Hubert, Collins, Combrink \& Verbeeten, 1995; Kasavana, Knuston \& Polonowski, 1997; Walle, 1996). These benefits include cost-savings (for instance cheaper advertising and lower expenditure on physical retail sites), speed, accessibility, communication of large volumes of information, customer convenience, improved customer relationship management, improved target marketing, and a world-wide reach for even the smallest tourism business. The implications of these benefits for smaller tourism businesses are particularly salient as the Internet can completely alter the ability of these businesses to compete in markets that were previously inaccessible, such as overseas markets (Haynes, Becherer \& Helms, 1998). Nevertheless, in spite of the Internet being uniquely equipped to provide dynamic and rich information to customers in an interactive setting (Barua, Konana, Whinston \& Yin, 2001), identifying the drivers of successful Internet marketing is proving to be challenging (Jingting \& Jinghua, 2004).
Although it can be argued that the utilisation of the Internet for marketing is what Clemons and Row (1991) call a "strategic necessity" for businesses, this information technology rarely has a direct impact on achieving a sustainable competitive advantage (SCA), but rather contributes indirectly as part of a complex chain of resources and capabilities (Wade \& Hulland, 2004). This approach to understanding the influence of information technologies on realising a SCA implies that although businesses may have equal access to the Internet, they may differ in their access to complementary strategic resources necessary to optimally utilise this medium. One approach to appreciating the factors driving the successful deployment of the Internet for marketing is the resource-based view (RBV) of the business (Powell \& Dent-Micallef, 1997; Zhuang \& Lederer, 2006).

This study attempts to use RBV as a means of identifying and empirically testing the complementary resources necessary for the successful implementation of the Internet for the marketing of small tourism businesses. The first consideration is the importance of taking a RBV of the business as a way of understanding Internet marketing within the context of small tourism businesses. Thereafter a 
number of potential drivers of Internet marketing success are identified and described, and the hypothesised relationships are empirically tested. The final sections are then used to consider the extent to which RBV has been successful in explaining the drivers of success in the use of the Internet for the marketing of tourism services. In following this approach, we hope to fill the considerable gap in the literature by understanding the extent to which small tourism businesses' unique, business-specific resources can contribute to the successful use of the Internet for marketing, and in so doing, ultimately contribute to a SCA.

\section{Resource-based view of the business}

The RBV of the business posits that a business is able to sustain a competitive advantage in respect of its competitors by owning certain resources (Barney, 1991; Grant, 1991; Wernerfelt, 1984). Although a number of frameworks have been developed to describe the nature of the resources needed to precipitate a SCA (for example Amit \& Schoemaker, 1993; Black \& Boal, 1994; Collis \& Montgomery, 1995; Grant, 1991), these are all consistent with the seminal article by Barney (1991), who proposes that resources need to be valuable, rare amongst a business's current and potential competition, imperfectly imitable, and not have strategically equivalent substitutes, to be able to sustain a competitive advantage. However, in order to use RBV theory to explain the drivers of Internet marketing success, it is first necessary to consider a theoretical link between Internet marketing and the RBV of the business.

Although it has been criticised for its inward focus (Hooley, Moller \& Broderick, 1998), and its static rather than dynamic nature (Teece, Pisano and Shuen, 1997), the concept of RBV has successfully migrated from strategic management to marketing (see for example Day, 1994; Hunt \& Morgan, 1995; Hunt \& Morgan, 1996; Hooley et al., 1998; Fahy \& Smithee, 1999) and has also been embraced in such areas of research as information systems (for example Wade \& Hulland, 2004) and e-commerce (Amit \& Zott, 2001). However, Zhuang \& Lederer (2006) point out that there is a significant gap in the e-commerce literature regarding the application of the RBV of a business as a means to understanding e-commerce performance. Compounding this problem with respect to small tourism businesses is the fact that most of these studies are related to the sellers of tangible goods (Powell \& Dent-Micallef, 1997; Zhuang \& Lederer, 2006), as opposed to services, and many of these studies have taken a theoretical rather than an empirical approach (Doherty \& Ellis-Chadwick, 2006).

A critical factor in assessing the success of integrating information technologies into the marketing of a business is the extent to which it contributes to the satisfaction of customer needs (Rust, 1999; Turban \& Gehrke, 2000). This view implies that a resource may be a source of competitive advantage if it is valuable to customers or enables the creation of value for customers (Fahy \& Smithee, 1999). However, one area which has eluded researchers in recent years is the extent to which the Internet may be able to provide or contribute to an SCA (e.g. Evans \& Wurster, 1997; Amit \& Zott, 2001; Nicholls \& Watson, 2005). Even though the Internet is at the core of e-commerce (Porter,
2001; Powell \& Dent-Micallef, 1997; Carr, 2003), the introduction of this information technology per se will not necessarily result in a SCA. A SCA may, however, be realised when this generic information technology is integrated with a business's unique organisational competencies (Feeny \& Willcocks, 1998; Wade \& Hulland, 2004) or its inimitable proprietary intellectual capital (Powell \& Dent-Micallef, 1997; Clemons \& Row, 1991). In other words, it is argued that while the implementation of the Internet for marketing does not in itself constitute a SCA, this may be achieved through the relationships and linkages between this information technology and other business assets and capabilities (Das, Zahra \& Warkentin, 1991; Wade \& Hulland, 2004).

\section{Internet marketing}

Our study attempts to build on extant research which has attempted to identify the resources required to allow businesses to leverage generic information technologies (IT), such as the Internet, to enhance the businesses' returns (Mata, Fuerst \& Barney, 1995). For example, Ross, Beath and Goodhue (1996) distinguish between IT assets and IT processes as components of information systems. IT assets are described as human assets, technology assets, and relationship assets, and IT processes are identified as planning ability, cost-effective operations and support, and fast delivery. A number of other authors have sought to add to this debate (for example, Bharadwaj, 2000; Powell \& Dent-Micallef, 1997) by extending existing typologies or proposing new classifications.

Durkin and McGowan (2001), for instance, built on this early research and have developed a theoretical model to describe the role and importance of the Internet for the marketing activities of entrepreneurial businesses. The model attempts to explain the competencies that a business would need to be able to migrate from the conceptualisation of the Internet as a marketing tool to the successful implementation of this information technology. Firstly, the entrepreneur should have a "vision" of what the Internet can achieve, and secondly, a competency defined by Durkin and McGowan (2001) as "value", which implies that the ownermanager takes his vision further and actually acquires the technology and technical competencies to utilise this medium. The third competency is that of "technical ability" and the last competency proposed is that of "control". This competency-based model implies that the owner-manager manages the Internet within the context of the overall business and marketing activities on a continuous basis, which means a high level of involvement on the part of the owner-manager (Durkin \& McGowan, 2001).

A common thread emerging from the literature is that the Internet per se cannot be a source of SCA, because the information technologies required to implement the Internet for marketing, are easily replicated by competitors (Lumpkin, Droege \& Dess, 2002), whereas non-technology assets such as complementary business and human resources cannot easily be reproduced (Powell \& Dent-Micallef, 1997; Zhuang \& Lederer, 2006). This approach is consistent with the "strategic necessity hypothesis" (Clemons \& Row, 1991) which proposes that the only way information technologies 
can contribute to an SCA for businesses is that the use of the Internet is driven by pre-existing business and human resources (Powell \& Dent-Micallef, 1997; Zhuang \& Lederer, 2006). This principle applies irrespective of the nature of the business or the industry (Das et al., 1991; Wade \& Hulland, 2004).

\section{Tourism marketing and small businesses}

The tourism industry has been identified as one of the key industries for driving economic development and economic transformation in developing countries (Rogerson, 2002a; Rogerson, 2002b). In many respects, the marketing challenges facing tourism businesses are unique in that these businesses cannot be promoted in isolation from their competing and complementary products (Middleton \& Clarke, 2001; Bennett, 2000). Compounding this challenge is the fact that the tourism industry is part of the service sector and the tourism product is predominately a service offering (Bennett, 2000; Middleton \& Clarke, 2001; Palmer, 2001), whereas much of the research on the factors driving the successful adoption of the Internet as a marketing tool have largely concerned physical goods (Powell \& DentMicallef, 1997; Zhuang \& Lederer, 2006).

A further distinguishing feature of the tourism sector is the predominance of small businesses (Buhalis, 1996, 1999; Buhalis \& Main, 1998; Middleton \& Clarke, 2001) although there is no settled definition of "a small business" (Hailey, 1992). It is trite to say that a small business is not merely a scaled-down version of a large business, and has a unique set of characteristics that differentiates it from its larger counterparts (Bridge, O’Neill \& Cromie, 1998; Chaston, 2000; Gilmore, Carson \& Grant, 2001; Stokes, 2000). Small businesses lack many of the resources typically available to larger businesses, and as a result find it difficult to compete with these bigger enterprises in terms of reaching target markets using the conventional marketing techniques (Stokes, 2000). Furthermore, the marketing practices of small businesses are influenced by such factors as the traits of the owner-manager, the size of the small, medium and micro enterprise (SMME), and its stage of development, all of which impact on their marketing techniques (Nilson, 1992).

It is therefore not surprising that what emerges from the literature is that one of the biggest barriers to small businesses in this sector reaching their potential is access to markets (Buhalis, 1996; Rogerson, 2003). The Internet, with its ability to reach broad and diverse markets at a very low marginal cost (Arthur, 1996; Buhalis \& Main, 1998; Carr, 2000), has the potential to contribute to the growth of this sector (Christian, 2001; Martin, 2004). Nevertheless, despite the promise of the Internet as a business and marketing tool for small businesses, actually harnessing this medium effectively is proving to be challenging (Öörni, 2004; Klein, Köhne \& Öörni, 2004) because many owner-managers do not understand the drivers of electronic commerce (Jingting \& Jinghua, 2004). However, in fairness to small tourism businesses, it must be pointed out that very little empirical evidence exists on which to base sound business decisions (Sigala, 2004), and that computer-mediated environments like the Internet can still be described as unique and very different from other physical windows of opportunity (Lee, Tan \& Lim, 2000; Turban, King \& Chung, 2000).

Against this backdrop, it is important to identify the business-specific factors that influence successful Internet marketing in small tourism businesses.

\section{Factors influencing internet marketing success}

The primary objective of this study is to investigate and empirically test the possible influences and relationships between the various independent variables and the dependent variable, namely the Perceived success of Internet marketing within the tourism industry. This study takes a RBV of the business in an attempt to identify the business-specific resources which drive the successful implementation of the Internet for marketing. These resources can be divided into three broad groups, namely tangible assets, intangible assets, and capabilities. Tangible assets are the fixed and current assets of a business, whereas intangible assets refer to assets such as intellectual property, brand equity and the businesses' formal and informal networks. Capabilities of businesses are seen as imperceptible assets, and comprise the skills of individuals in the business as well as its organisational culture and practices (Fahy \& Smithee, 1999).

The value of taking a RBV of the business is that this theory proposes that achieving a sustainable competitive advantage (and consequently above-average returns) results from owning certain key resources (Beard \& Sumner, 2004). It is therefore important that management identify and acquire these resources if businesses are to create and sustain a competitive advantage (Fahy \& Smithee, 1999; Clemons \& Row, 1991). The primary objective of this study is to consider the contributions of certain resources, in an attempt to explain the extent to which these competencies and assets can explain Internet marketing success, and how they contribute to a SCA. The factors identified and empirically evaluated in this study are (a) the owner-manager of the tourist business acting as product champion: (b) ownermanager knowledge and (c) alliances.

This study can be distinguished from earlier studies in that it focuses on small tourism businesses. The business-specific resources (Del Aguila-Obra \& Padilla-Meléndez, 2006) driving the successful implementation of an information technology (such as the Internet for marketing), may differ. Nevertheless, our study augments previous work such as the study of Powell and Dent-Micallef (1997) who, taking a RBV of the business, used three resources - "information technology resources", "human resources" and "business resources"- to predict IT performance and business performance. This study was adapted by Zhuang and Lederer (2006) to investigate the impact of what they termed "complementary human resources" and "complementary business resources" on e-commerce performance (as well as business performance). These findings are consistent with the resources identified in the present study as potential drivers of Internet-marketing success. Specifically, the owner-manager of a small tourism business acting as a product champion and the knowledge of the ownermanager, are complementary human resources, whereas 
alliances can be classified as complementary business resources (Powell \& Dent-Micallef, 1997; Zhuang \& Lederer, 2006).

\section{Alliances}

Alliances can take a number of forms (Dean \& Holmes, 1997) and include personal contact networks, social networks, business networks, industry networks and marketing networks (Gilmore et al., 2001; Piercy \& Cravens, 1995). A number of terms such as "confederations of specialists", "networks" and "alliances" are used to describe these cooperative relationships (Piercy \& Cravens, 1995). These inter-personal relationships take on a particular importance for small businesses when utilising the Internet as a marketing tool (Jones, Hecker, \& Holland, 2003; McGowan \& Durkin, 2002).

Alliances play a crucial role in small business marketing by reducing uncertainty and facilitating trust, in so doing, reducing the risk for all the parties (McGowan, Durkin, Allen \& Nixon, 2001; Morrison, Lynch \& Johns, 2004). These networks are also used by small businesses to access market information (Carson, Cromie, McGowan \& Hill, 1995), as small businesses often do not have the time or resources to buy market information or solicit the services of business consultants (Collinson \& Shaw, 2001; Christian, 2001). Not only do alliances contribute to the information resources of small businesses, but they also have an influence on their decision-making (Collinson \& Shaw, 2001; Hill \& McGowan, 1996; Morrison et al., 2004). Accordingly it is hypothesised that:

\section{$\mathrm{H}^{1}$ : There is a positive relationship between the existence of alliances and the perceived success of Internet marketing.}

Small businesses may lack the specialised knowledge necessary for the successful planning and implementation of Internet technology to realise their business objectives (Jones et al., 2003) and consequently, cooperative behaviours should allow these enterprises to expand their knowledge and assist in overcoming resource weaknesses (Gretzel et al., 2000) in respect of Internet marketing (McGowan \& Durkin, 2002; McGowan et al., 2001). These collaborative relationships are particularly important to small businesses, as acquiring the resources to utilise the Internet for marketing purposes may not be feasible (Jones et al., 2003).

Besides the cost-effectiveness of using alliances, it must be acknowledged that many tourists regard a destination as a combination of all the individual tourism businesses and attractions (Bennett, 2000; Palmer \& McCole, 2000; Middleton \& Clarke, 2001; Morrison et al., 2004). Being involved in an alliance-type arrangement would thus directly enhance the chances of successful Internet marketing for a small tourism business, and would also enhance the ownermanager's knowledge of Internet marketing via this interaction (Gretzel et al., 2000; Hoffman \& Novak, 1997). In this way an alliance could indirectly impact on successful Internet marketing. With this in mind, the following hypothesis is formulated:
$\mathrm{H}^{2}$ : The extent of alliances is positively related to the extent of the owner-manager's knowledge of the business implications of marketing over the Internet.

\section{Owner-manager knowledge}

Some level of technical knowledge by the owner-manager has been found to be an important factor in the successful adoption and implementation of information technology systems (Cragg \& King, 1993; Thong \& Yap, 1995; Wade \& Hulland, 2004), as it has been for the Internet (McGowan \& Durkin, 2002; Mehrtens, Cragg \& Mills, 2001).

In order to integrate the Internet as a core tool for marketing, Durkin and McGowan (2001) posit that "technical ability" is a competency that needs to be acquired by the ownermanager. They argue that while the level of expertise required does not necessarily imply that the owner-manager is able to implement all the technical attributes of this technology, owner-managers should at least appreciate the fundamental issues of using and managing the Internet.

Others argue that innovations such as the Internet require a knowledge that is greater than a general appreciation of the technology (Jones et al., 2003; Shane \& Venkataraman, 2000). These authors suggest that the successful implementation of complex innovations (such as the Internet), in addition to a basic understanding of the principles, requires specialised knowledge of how to operate the technology (Rogers, 1995; Wade \& Hulland, 2004). Accordingly, we predict that:

\section{$\mathrm{H}^{3}$ : There is a positive relationship between the extent of the owner-manager's knowledge of the business implications of marketing over the Internet and the perceived success of Internet marketing.}

Another school of thought believes that the owner-manager of a small business does not necessarily have to have the technical competence to implement the Internet personally, as much of the required knowledge could be sourced from his personal contact network (McGowan et al., 2001). Nevertheless, a reasonable knowledge and understanding of the Internet by the owner-manager of a small business is necessary for the successful implementation of the Internet for marketing (Marshall, Sor \& McKay, 2000; Stansfield \& Grant, 2003), as often only the owner-manager appreciates the critical issues in a small business, and is in a position to make informed decisions (O'Toole, 2003; Delone, 1988). It thus appears that the knowledge that owner-managers of small tourism businesses have of the Internet is related to the successful use of the Internet for marketing purposes.

In order to act as a product champion, it would be expected that the owner-manager would have a reasonable understanding of the technology (Stansfield \& Grant, 2003; Wade \& Hulland, 2004), although this would not necessarily consist of formal training (Poon \& Swatman, 1999). Thus, we also expect owner-manager knowledge to be positively related to the owner-manager's ability to act as a product champion. The following hypothesis addresses this proposition: 
$\mathrm{H}^{4}$ : The extent of the owner-manager's knowledge of the business implications of marketing over the Internet is positively related to the extent to which the ownermanager is a product champion.

\section{Owner-manager as product champion}

Product champions are people who recognise the potential of a particular project, and take the necessary action to implement the innovation. Although many of the issues surrounding the implementation of an innovation in a large business may not be relevant for small businesses, one area of overlap is the enthusiasm of the product champion (Markham \& Aiman-Smith, 2001).

The embracing of the Internet by owner-managers as an important medium to achieve the businesses' goals is a critical factor in its adoption and successful utilisation (Bengtsson, Boter \& Vanyushyn, 2003; Mehrtens et al., 2001; Stansfield \& Grant, 2003). It follows that if Internet marketing is to be successful in small tourism businesses, the owner-manager should act as a product champion in respect of this initiative. Indeed, research (Bengtsson et al., 2003) suggests that a product champion for the use of the Internet for marketing may be more important for small- and medium-sized businesses than for large businesses.

The importance of a product champion for the successful implementation of an innovation is confirmed in a number of studies (Cragg \& King, 1993; Ettlie, Bridges \& O’Keefe, 1984) and the Internet is indeed one of the most significant innovations of our time (Bengtsson et al., 2003; Mehrtens et al., 2001). This conclusion is consistent with research conducted in respect of the successful adoption and implementation of IT by small businesses, research has found that management/owner enthusiasm concerning the initiative is a critical factor in its successful implementation (DeLone, 1988; Thong \& Yap, 1995).

We thus argue that having the owner-manager as a product champion in a small tourism business will enhance the chances of successful Internet marketing in the business. In other words, we propose that:

\section{$\mathrm{H}^{5}$ : There is a positive relationship between the owner- manager being a product champion in respect of marketing over the Internet and the perceived success of Internet marketing.}

The methodology used to test the hypotheses formulated above is discussed in the next section.

\section{Methodology}

\section{The measuring instrument}

There are few reliable scales to measure most of the aspects related to e-business ( $\mathrm{Wu}$, Mahajan \& Balasubramanian, 2003), and in the absence of objective measures, subjective assessments (Owner-managers' perceptions of performance) can be used as satisfactory proxies for business-economicperformance measures (Dess \& Robinson, 1984; Venkatraman \& Ramanujam, 1987). The importance of multidimensional measures of business performance (Venkatraman \& Ramanujam, 1987) and e-commerce success (Molla \& Licker, 2001) has been recognised. Consequently, a ten-item scale has been developed to measure the dependent variable, the perceived success of Internet marketing, based on the scales developed by $\mathrm{Wu}$ et al. (2003) and Zhuang and Lederer (2006).

In respect of the independent variable, Product champion, six items were selected from a number of developed scales designed to measure this construct (Bengtsson et al., 2003; Thong \& Yap, 1995; Moore \& Benbasat, 1991; Zhuang \& Lederer, 2006) and for Alliances, six items based primarily on the four-item scale developed by Kickul and Walters (2002) was used to measure external relationships, with an additional two items developed from the literature (for example Choudhury, Hartzel \& Konsynski, 1998; Powell \& Dent-Micallef, 1997; Zhuang \& Lederer, 2006). Although there were no existing scales available to measure Ownermanager Knowledge (of Internet marketing), the scale developed by Thong and Yap (1996) to measure CEO IT knowledge was adapted and a six-item scale was consequently used to measure this construct.

In order to develop and validate the instrument where no pre-existing measures were available or inadequate, a number of steps were taken. First the literature was surveyed, and thereafter the questionnaire was reviewed by five academic researchers at a research colloquium. The academics were requested to provide feedback on the design of the measurement scales, and their inputs were taken into consideration in improving the measurement scales. Thereafter the questionnaire was tested with ten respondents from the population group. This pilot-test took the form of an interview in which the participant was handed a copy of the questionnaire and asked to discuss any queries or ambiguities in the questionnaire. The object of this exercise was to assess the time it took to complete the questionnaire, the clarity of the instructions, and the comprehensibility to the respondents of the questions and terminology used. As a result of this pilot-study, amendments were made to improve the questionnaire.

All the items in the questionnaire were linked to a 7-point Likert-type scale where 7 was labelled Strongly agree and 1 was labelled Strongly disagree.

\section{The sample}

The databases of tourism businesses registered with tourism associations responsible for marketing of the destination in which the small businesses were situated, were used as the sampling frame. These databases were used to elicit the contact details of those small tourism businesses with Websites which were used as the qualifying criterion to define those tourism businesses which use the Internet to market their tourism businesses. Furthermore, "small businesses", for the purposes of this study, were defined as businesses that had 100 or less employees. In order to verify that businesses complied with this requirement, the questionnaire required that the respondents indicate the number of people employed in their respective businesses. From the sample frame, 2011 small tourism businesses 
were surveyed, and the 316 usable questionnaires returned (a response rate of $15,7 \%$ ), comfortably exceeded the minimum guideline for the use of multivariate statistical procedures to analyse the data (Hair, Anderson, Tatham, \& Black, 1998). The questionnaires were completed by the owner-managers of the small tourism businesses.

\section{Statistical procedures}

In this study structural equation modelling (SEM) was used to measure the relationships between the variables in a theoretical model in preference to the use of a regression analysis, as a multiple regression analysis can examine only a single relationship at a time (Hair, Anderson, Tatham \& Black, 1995). SEM thus enables the researcher to examine a series of interdependent relationships simultaneously. In addition, SEM, unlike regression analysis, allows a researcher to estimate the relationships among constructs that are free from measurement error (Raykov, Tomer \& Nesselroade, 1991). This benefit is important because most measures used in marketing and consumer research reflect not only the construct they are intended to represent, but also random and systematic measurement error.

The model was assessed using a SEM approach. This was done using LISREL 8.54 (Jöreskog \& Sörboom, 2003). The assessment of the model was, however, preceded by an assessment of the discriminant validity of the instrument, using an exploratory factor analysis and subsequently by an assessment of its internal reliability of the instruments used to measure the variables in the theoretical model.

\section{The empirical results}

\section{Discriminant validity results}

The exploratory factor analysis was conducted using the computer program SPSS. Maximum likelihood was used as the method of factor extraction, and an Oblimin with Kaiser normalisation was specified as the rotation method (Jennrich \& Sampson, 1996). Initially the number of factors to be extracted was not specified. The Eigen values in combination with the scree test suggested, however, that the extraction of four variables would be appropriate.

These factors were identified by an iterative process, deleting items that either did not load significantly (loadings $>0.40$ were regarded as significant) or loaded on two or more factors (cross-loading). The most interpretable factor structure to emerge from this iterative process was the one depicted in Table 1.

The factor matrix shown in Table 1 shows that after 11 iterations, 23 items loaded on four distinct factors explaining a total of $70 \%$ of the variance. The four factors in Table 1 are named Perceived success of Internet marketing (the dependent variable) Owner-manager knowledge, Product champion and Alliances.

In this study, the construct Product champion was defined as the degree to which the owner-manager appreciate what the Internet can do for the marketing of the business, and is excited, passionate, enthusiastic and committed to its use in the marketing of the business. Of the seven items expected to measure Product champion, four items (PC1, PC2, PC3 and PC4) loaded on a single factor as expected together with two additional items (TK1 and TK6). These items refer to the appreciation by the owner-manager of what the Internet can do for the marketing of the business, and were regarded as additional measures of the Product champion variable.

\section{Table 1: Exploratory factor analysis results}

\begin{tabular}{|c|c|c|c|c|}
\hline Item & $\begin{array}{c}\text { Factor } 1 \\
\text { Perceived } \\
\text { success of } \\
\text { internet } \\
\text { marketing }\end{array}$ & $\begin{array}{c}\text { Factor } 2 \\
\text { Owner- } \\
\text { manager } \\
\text { knowledge }\end{array}$ & $\begin{array}{c}\text { Factor } 3 \\
\text { Product } \\
\text { champion }\end{array}$ & $\begin{array}{l}\text { Factor } 4 \\
\text { Alliances }\end{array}$ \\
\hline SUC9 & 0,892 & & & \\
\hline SUC10 & 0,780 & & & \\
\hline SUC8 & 0,676 & & & \\
\hline SUC7 & 0,642 & & & \\
\hline SUC5 & 0,568 & & & \\
\hline SUC4 & 0,566 & & & \\
\hline SUC6 & 0,488 & & & \\
\hline SUC3 & 0,423 & & & \\
\hline TK4 & & 0,922 & & \\
\hline TK3 & & 0,876 & & \\
\hline TK5 & & 0,803 & & \\
\hline TK2 & & 0,706 & & \\
\hline PC1 & & & 0,901 & \\
\hline PC2 & & & 0,857 & \\
\hline TK1 & & & 0,799 & \\
\hline PC3 & & & 0,727 & \\
\hline PC4 & & & 0,621 & \\
\hline PC7 & & & 0,602 & \\
\hline TK6 & & & 0,517 & \\
\hline ALI3 & & & & 0,782 \\
\hline ALI4 & & & & 0,684 \\
\hline ALI2 & & & & 0,572 \\
\hline ALI5 & & & & 0,417 \\
\hline
\end{tabular}

Note:

1. Loadings of greater than 0.40 were considered significant

2. The items used to measure the different factors are shown in full in Appendix A.

Factor 2 was labelled Owner-manager knowledge and comprised the remaining four items (TK2, TK3 TK4 and TK5) of the six items expected to measure the construct. Accordingly, the construct of Owner-manager knowledge was operationalised as the extent to which the ownermanager of a small tourism business appreciates, monitors and understands the business implications of the Internet, which allows him to make informed decisions about the use of the Internet for marketing purposes.

Alliances was the name given to Factor 3. In this study, Alliances refers to the extent to which small tourism businesses use contact networks as a resource to plan and implement their Internet marketing strategy. Six items were used to measure the construct Alliances, four of which loaded on one factor, as expected. Two items (ALI1 and ALI6) did not load on any factor and were deleted.

The results of the exploratory factor analysis revealed that the independent variables in this study demonstrated 
sufficient discriminant validity. Table 1 shows three distinct underlying factors that are interpretable, and in addition each item measures only one underlying construct. These three factors or variables were regarded as the independent variables impacting on the dependent variable, Perceived success of Internet marketing.

The dependent variable: Perceived success of Internet marketing

The multidimensional nature of marketing and business performance suggests that no individual measure is adequate to measure these nebulous concepts (Kline, Morrison \& John, 2004; O'Connor, 2004; Wade \& Hulland, 2004). To measure the dependent variable of Perceived success of Internet marketing, ten items were derived from the literature (for example Molla \& Licker, 2001, Wu et al., 2003; Dess \& Robinson, 1984; Venkatraman \& Ramanujam, 1987) and preliminary qualitative research (for example interviews with industry experts and owner-managers of small tourism businesses). The ten items developed to measure this construct were subjected to a factor analysis, and eight items (SUC3-10) loaded on this factor.

\section{Reliability results}

All of the factors identified in Table 1 (including the dependent variable) returned a Cronbach alpha coefficient score in excess of 0,70 and the data were thus regarded as reliable (Nunnally \& Bernstein, 1994).

\section{Structural equation modelling results}

To assess the multivariate normality of the data, the following null hypothesis was considered:

\section{$\mathrm{H}^{0}$ : The data distribution is a multivariate normal distribution.}

As the value for the Chi square test statistic was 7324.3 and the associated p-value smaller than 0,001 , the null hypothesis had to be rejected at the $0,1 \%$ level of significance. In other words, the assumption of multivariate normality was not supported by the data. As a result, the Robust Maximum Likelihood method available in LISREL 8,54 (Jöreskog \& Sörboom, 2003) was used for estimating both the measurement model and the structural equation model.

\section{The measurement model}

The specification of the indicators of the measurement model is shown in Table 2. It consists of the four constructs (factors) that emerged from the exploratory factor analysis stage, and the manifest variables that define these constructs. In addition, the dependent variable, Perceived success of Internet marketing, is also reflected together with its manifest variables.

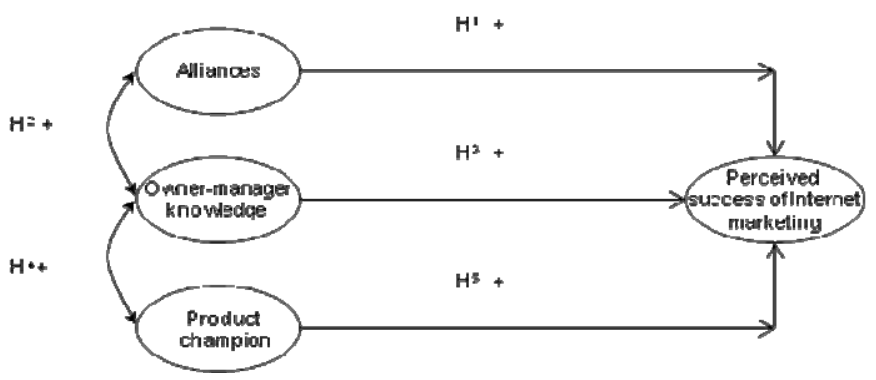

Figure 1: The theoretical model

Table 2: Definition of measurement model

\begin{tabular}{l|l}
\hline Constructs & Manifest variables \\
\hline Product champion & $\begin{array}{l}\text { PC1, PC2, TK1, PC3, PC4, } \\
\text { PC7,TK6 }\end{array}$ \\
\hline $\begin{array}{l}\text { Owner-manager } \\
\text { knowledge }\end{array}$ & TK4, TK3, TK5, TK2 \\
\hline Alliances & ALI3, ALI4, ALI2, ALI5 \\
\hline $\begin{array}{l}\text { Perceived success of } \\
\text { Internet marketing }\end{array}$ & $\begin{array}{l}\text { SUC9, SUC10, SUC8, SUC7, } \\
\text { SUC5, SUC4, SUC6, SUC3, }\end{array}$ \\
\hline
\end{tabular}

Estimation of goodness-of-fit for the measurement model

In respect of each manifest variable included in the measurement model, the p-values associated with each of the loadings exceed the critical value $(2,58)$ at the $1 \%$ significance level. It can therefore be concluded that the manifest variables are significantly related to their individual constructs.

The non-normality of the data meant that the goodness-of-fit measures of goodness-of-fit index (GFI) and adjusted goodness-of-fit index (AGFI) could not be used to assess the overall fit of the measurement model. Because of the nonnormality of the data, the Satorra-Bentler Scaled Chi-Square $\left(\mathrm{SBS} \chi^{2}\right)$ (Satorra \& Bentler, 1994) was used instead of the standard Chi-Square $\left(\mathrm{SBS} \chi^{2}=0.438\right)$.

Although there is some conjecture on the topic, a value of less than or equal to 3,0 for the $\mathrm{SBS} \chi^{2} /$ degrees of freedom ratio is used as an indication of reasonable fit (Kline, 1998). In respect of the measurement model, the root mean square error of approximation RMSEA score of 0,0551 falls between 0,05 and 0,08 , indicating a reasonable fit, and this conclusion is supported by the $\mathrm{SBS} \chi^{2} /$ degrees of freedom ratio, which is 1,96 and below the threshold of 3.0. In other words, the goodness-of-fit statistics provide considerable support for the contention that the data fits the measurement model reasonably well.

\section{Estimation of structural model}

The Robust Maximum Likelihood method of estimation was also used in respect of the structural model. The results are presented in Figure 2. 


\section{Evaluating the goodness-of-fit of the structural model}

In respect of each manifest variable included in the measurement model, the p-values associated with each of the loadings exceed the critical value $(2.58)$ at the $1 \%$ significance level. It can therefore be concluded that the manifest variables are significantly related to their individual latent variables.

The non-normality of the data meant that the goodness-of-fit measures of goodness-of-fit index (GFI) and adjusted goodness-of-fit index (AGFI) could again not be used to assess the overall fit of the structural model. Because of the non-normality of the data, the Satorra-Bentler Scaled ChiSquare $\left(\mathrm{SBS} \chi^{2}\right.$ ) (Satorra \& Bentler, 1994) was used instead of the standard Chi-Square $\left(\mathrm{SBS} \chi^{2}=0.438\right)$.

Similarly, in respect of the structural model, the root mean square error of approximation RMSEA score of 0.0551 falls between 0.05 and 0.08 , indicating a reasonable fit, and this is supported by the $\mathrm{SBS} \chi^{2} /$ degrees of freedom ratio, which is 1.96 and below the threshold of 3.0. In other words, the goodness-of-fit statistics provide considerable support for the structural model.

\section{Structural model results}

Figure 2 reflects the structural model tested in this study. The results in respect of the impact (both direct and indirect) of the independent variables Alliances, Owner-manager knowledge and Product champion on the dependent variable, Perceived success of Internet marketing are considered in the next section.

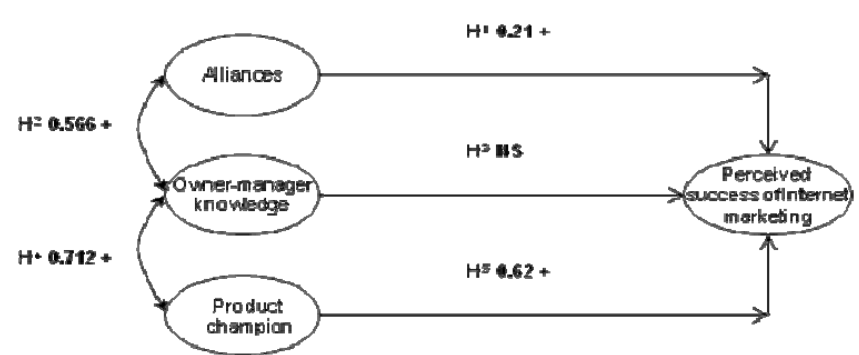

Figure 2: Structural model estimation

\section{Alliances}

Hypothesis $\mathrm{H}^{1}$ is accepted as the current study revealed a significant positive relationship $(0.21, \mathrm{p}<0.01)$ between Alliances and the Perceived success of Internet marketing. In other words, the more the owner-manager makes use of alliances as a resource to plan and implement the use of the Internet for marketing, the more likely it is that the Internet marketing of the tourist business will be perceived as successful. One reason for this relationship is that small businesses usually suffer from a lack of resources, and networks expand the resources of small businesses (Christian, 2001; McGowan \& Durkin, 2002; McGowan et al., 2001; Morrison et al., 2004), which is critical to the success of Internet marketing. In addition, alliances may add value in terms of developing new products and ways of marketing products, using the Internet (Hoffman \& Novak, 1997; Gilmore et al., 2001; Gretzel et al., 2000; Jones et al., 2003).

Cooperative behaviours allow businesses to expand their knowledge (Gretzel et al., 2000; Morrison et al., 2004). The empirical results in the present study support this line of reasoning, showing a positive relationship $(0.566, \mathrm{p}<0.0001)$ between Alliances and Owner-manager knowledge (Hypothesis 2). This result would imply that the more the owner-manager makes use of alliances, the more the ownermanager's knowledge about the use of the Internet for marketing will be enhanced. In other words, Hypothesis 2 is accepted.

\section{Owner-manager knowledge}

No empirical support was found for the hypothesised relationship between Owner-manager knowledge and Perceived success of Internet marketing as reflected in Figure 2. In other words, whether the owner-manager appreciates the business potential of the Internet or not will have no direct impact on the success of the Internet marketing of a small tourism business. Hypothesis $\mathrm{H}^{3}$ is accordingly rejected.

This finding is inconsistent with research concerning information systems (for example Cragg \& King, 1993; Thong \& Yap, 1995), which found that, while ownermanagers did not need to be experts in information technology, a reasonable level of technical knowledge is important for its successful adoption and implementation. However, these findings (Cragg \& King, 1993; Thong \& Yap, 1995) can be distinguished from the research in regard to the use of Internet for marketing, which emphasises the importance of the owner-manager appreciating and understanding the broader business implications of the Internet for marketing, in order to coordinate this medium to achieve marketing goals, as opposed to an understanding of the technology per se. Nevertheless, the empirical findings in this study contradict the research relating to the importance of the owner-manager's grasp of the business implications of the use of the Internet for marketing (Mehrtens et al., 2001; McGowan \& Durkin, 2002).

This study, does, however show that Owner-manager knowledge does have an indirect influence on the Perceived success of Internet marketing. This study reveals a positive relationship $(0,712, \mathrm{p}<0,001)$ between the Owner-manager knowledge and Product champion, and Hypothesis $\mathrm{H}^{4}$ is accepted. This finding is consistent with research that found that in order to act as a product champion, it would be expected that the owner-manager would have a reasonable understanding of the technology (McGowan \& Durkin, 2002; Stansfield \& Grant, 2003).

\section{Product champion}

It is apparent from Figure 2 that there is a strong positive relationship $(0,62, \quad \mathrm{p}<0,0001)$ between the Product champion and the Perceived success of Internet marketing. This finding suggests that, where the owner-manager acts as product champion for the use of the Internet for the 
marketing of the small tourism business, this initiative will be more likely to be successful. It follows that $\mathrm{H}^{1}$ is accepted.

This result is consistent with the argument that the use of the Internet can be regarded as an innovation (Bengtsson et al., 2003; Mehrtens et al., 2001) and that relating to the successful adoption and implementation of innovations, a product champion is important (Cragg \& King, 1993; Ettlie et al., 1984). In addition, the significance of the ownermanager acting in the role of product champion is consistent with past research with regard to the importance of a product champion in successfully employing the Internet for marketing purposes (Bengtsson et al., 2003; Mehrtens et al., 2001; Stansfield \& Grant, 2003; Thong \& Yap, 1995). Similarly, the implications of an owner-manager acting as a product champion suggest that the owner-manager will have a vision of the potential of Internet marketing, which is an important component in achieving Internet marketing success (Durkin \& McGowan, 2001; McGowan \& Durkin, 2002; McGowan et al., 2001).

\section{Managerial implications}

As businesses competing in the same industry acquire comparable resources over time, competitive advantage becomes more difficult to sustain (Beard \& Sumner, 2004). Small businesses operating in the online environment are particularly prone to the threat of competitors copying their online strategy (Lumpkin et al., 2002) given that a business's Web-based online strategy is usually fairly transparent and thus easily imitable (Carr, 2003). Consequently, in the absence of other business-specific factors, it will be difficult to sustain an online competitive advantage (Porter, 2001). This is because, in terms of RBV theory, having the same resources as other businesses cannot be a source of competitive advantage.

Resource theory has been applied and been accepted in a number of management disciplines, and is a useful way of appreciating the strategic value of resources vis $a$ vis successful Internet marketing. The RBV of the business proposes that individual and disparate resources rarely act autonomously in facilitating, whether directly or indirectly, a SCA. This implies that IT can only be a source (or contributor to SCA) if properly integrated with other complementary business-specific resources. One important driver of Internet marketing success highlighted by the empirical results is Alliances, a concept which has a direct influence on the Perceived success of Internet marketing, as well as an indirect influence through its influence on Ownermanager knowledge. The importance of alliances with competing or complementary businesses lies not only in the likelihood of accessing knowledge resources for the ownermanager, but also with the opportunities they present in terms of creating new products and opportunities.

It is a truism that, for tourists, a destination comprises a cluster of products (comprising both goods and services), rather than an individual tourism product. This contention is valid even if the reason for visiting a particular destination is because of one dominant or central attraction or feature. A destination is usually viewed as a conglomeration of tourism features and natural attractions, and consequently, it is unrealistic for a business to ignore other tourism operations. These "competitors" can also be a resource that can be utilised to enrich the Internet marketing of a business. Shared learning experiences, ideas, contacts or joint ventures with competitors are all techniques that can be used to overcome the barriers faced by small businesses. These informal partnerships may allow businesses to access tools and resources that would otherwise not be feasible for individual small tourism businesses, and latecomers can benefit from the experiences of those competitors (and complementary businesses) with whom small tourism businesses form alliances.

The study also found that Owner-manager knowledge of the broader business or marketing implications of the Internet, has an important impact on the Perceived success of Internet marketing. This influence is indirect as a result of influence on the variable Product champion. This result suggests that if the owner-manager has a comprehensive understanding of the issues surrounding the implementation of the Internet for marketing of the business, this will have a positive influence on his ability to act as a product champion.

The literature is unclear on the precise nature and extent of the knowledge required by the owner-manager to successfully utilise the Internet for marketing purposes. Although the owner-manager needs some level of technical competence, this does not necessarily have to be to the extent of being able to implement the technology. Similarly, it is unclear whether this capacity will translate into a capability to see the Internet in a broader business or marketing context. The implications of this finding are that the acquisition of technical skills by the owner-manager, whether by formal course or experience, will not necessarily add value to Internet marketing unless this is accompanied by the ability to appreciate the broader business implications of these skills.

One source of this expertise could be alliances, which would give the owner-manager the chance to acquire knowledge on a "need to know" basis, without having to waste time and resources by attending a formal course. Information from alliances is also likely to be more judicious and better able to identify the critical success factors for Internet marketing in a specific context than the generic (and probably inappropriate) learning obtained from most commercial education providers. This is not to say that these businesses do not have their place in the broader economy, but rather that small tourism businesses have specific needs and requirements that are unique.

The owner-manager acting in the role of Product champion concerning the use of the Internet for marketing, yet again, stresses the dominant and influential role played by the owner-manager in the affairs of small businesses.

Although the literature overwhelmingly agrees on the significance of a Product champion in the implementation of the Internet for marketing, there is some conjecture on the level of importance of this factor. There is a contention that the less complex the information technology, the less important the role of the product champion. This argument, 
however, ignores the context of the implementation of the Internet. What may, from an objective technological viewpoint, be a relatively simple and ubiquitous technology, may still be a complex and challenging assignment for a small business with limited resources and experience in the area. The results confirm that product champions are an important catalyst in the success of an IT, such as the use of the Internet for marketing.

Having an online marketing presence does not necessarily lead to improved marketing and concomitant financial rewards. Utilising the Internet for marketing in the small tourism business context, in addition to the financial investment, implies a certain level of emotional commitment by the owner-manager. The excitement, enthusiasm, passion and commitment with which the owner-manager embraces the use of the Internet for marketing, generates support for the project amongst employees of the business. This is particularly pertinent in high-contact service businesses such as small tourism businesses where, given the inseparability of production and consumption, employees are an important part of the marketing communication process.

In conclusion, this study contributes to the literature in a number of ways. Firstly, it has identified and measured the impact of the internal resources in small tourism businesses that are necessary to successfully implement the Internet for marketing. Secondly, this study has established that RBV is an appropriate perspective from which the drivers of Internet marketing success can be understood and explained, which is understandable given the grounding of this theory in economic theory (Clemons \& Row, 1991). In other words, this study concludes that while the use of the Internet for marketing can be an important factor in the success of small tourism businesses, any competitive advantage is unlikely to be sustainable in the absence of complementary resources and competencies.

\section{Limitations of the study}

One limitation of the study is that perceptions were measured. In other words, the study reports what the managers of small tourism establishments believe is the case, rather than "hard facts". For instance, the success of their Internet marketing endeavours were not measured in terms of "hits", number of bookings over the Internet, or the absolute returns generated. However, given the sensitivity and complexity of financial measures, it is unlikely that such measures of success would have been readily available or readily forthcoming. Furthermore, there are no absolute measures for evaluating marketing performance, and it essentially comprises measuring results against expectations (Bonoma, 1989; Connor \& Tynan, 1999). This difficulty is compounded in regard to Internet marketing, as it is difficult to isolate the impact of this medium on various measures of success (Chaffey, Mayer, Johnston \& Ellis-Chadwick, 2000).

In addition, only organisational variables impacting specifically on the Internet marketing success were investigated. More objective assessments of marketing success and the inclusion of a wider variety of variables that can drive Internet marketing success, leave scope for future research. Nevertheless, we believe that our research makes an important contribution by extending the application of resource-based theory to appreciating the implications of business-specific resources for the success of Internet marketing.

\section{References}

Amit, R. \& Schoemaker, P. J. H. 1993. 'Strategic assets and organizational rent', Strategic Management Journal, 14(1): 33-46.

Amit, R. \& Zott, C. 2001. 'Value creation in e-business', Strategic Management Journal, 22(1): 493-520.

Arthur, B. W. 1996. 'Increasing returns and the new world of business', Harvard Business Review, 74(4): 100-109.

Barney, J.B. 1991. 'From resources and sustained competitive advantage', Journal of Management, 17(1): 99120.

Barua, A., Konana, P., Whinston, A. B. \& Yin, F. 2001. 'Driving E-business excellence', MIT Sloan Management Review, 43(1): 36-44.

Beard, J.W. \& Sumner, M. 2004. 'Seeking strategic advantage in the post-net era: Viewing ERP systems from the resource-based perspective', Journal of Strategic Information Systems, 13(2): 129-50.

Bengtsson, M., Boter, H. \& Vanyushyn, V. 2003. 'The challenge of building marketing channels via the Internet'. Proceedings of the International Council for Small Business (ICSB) 2003 Conference, 15-18th June Belfast, Northern Ireland.

Bennett, J. A. 2000. 'What is tourism?' In Bennett, J. A. Ed. Managing tourism services. 2nd Edition. Pretoria: Van Schaik Publishers.

Bharadwaj, A. S. 2000. 'A resource-based perspective on information technology capability and firm performance: An empirical investigation', MIS Quarterly, 24(1): 169-196.

Black, J. A. \& Boal, K. B. 1994. 'Strategic resources: Traits, configurations and paths to sustainable competitive advantage', Strategic Management Journal, 15(1): 131-148.

Bonoma, T. V. 1989. 'Marketing performance - What do you expect?' Harvard Business Review, 67(5): 44-47.

Bridge, S., O’Neill, K. \& Cromie, S. 1998. Understanding enterprise, entrepreneurship and small business. London: MacMillan Press Ltd.

Buhalis, D. 1996. 'Enhancing the competitiveness of small and medium-sized tourism enterprises', Electronic Markets, 6(1): 1-6.

Buhalis, D. 1999. 'Information technology as a strategic tool for sustainable tourism development', The Courier, 175 (May- June): 55-57. 
Buhalis, D. \& Main, H. 1998. 'Information technology in peripheral small and medium hospitality enterprises: Strategic analysis and critical factors', International Journal of Contemporary Hospitality Management, 10(5): 198-202.

Carr, N. G. 2000. 'Hypermediation: Commerce as clickstream', Harvard Business Review, 78(1): 46-47.

Carr, N. G. 2003. 'IT doesn't matter', Harvard Business Review, 81(5): 41-49.

Carson, D. J., Cromie, S., McGowan, P. \& Hill, J. 1995. Marketing and entrepreneurship in SMEs: An innovative approach. London: Prentice Hall.

Chaffey, D., Mayer, R., Johnston, K. \& Ellis-Chadwick, F. 2000. Internet marketing, strategy, implementation and practice. Harlow, UK: Prentice Hall.

Chaston, I. 2000. Entrepreneurial marketing: Competing by challenging convention. London: Macmillan.

Choudhury, V.H, Hartzel, K. S. \& Konsynski, B.R. 1998. 'Uses and consequences of electronic markets: An empirical investigation in the aircraft parts industry', MIS Quarterly, 22(4): 471-507.

Christian, R. 2001. 'Developing an online strategy: Issues facing small to medium-sized tourism and hospitality enterprises', Journal of Vacation Marketing, 7(2): 170-178.

Clemons, E. K. \& Row, M. C. 1991. 'Sustaining competitive advantage: The role of structural differences', MIS Quarterly, 15(3): 275- 292.

Collinson, E. \& Shaw, E. 2001. 'Entrepreneurial marketing - A historical perspective on development and practice', Management Decision, 39(1): 761-766.

Collis, D. J. \& Montgomery, C. A. 1995. 'Competing on resources: Strategy in the 1990s', Harvard Business Review, 73(4): 118-128.

Connor, P. \& Tynan, C. 1999. 'In sickness and in health: Exploring and redeveloping a measure of marketing effectiveness', Journal of Marketing Management, 15(8): 733-756.

Cragg, P. B. \& King, M. 1993. 'Small firm computing: Motivators and inhibitors', MIS Quarterly, 17(1): 47-60.

Das, S. R., Zahra, S. A. \& Warkentin, M. E. 1991. 'Integrating the content and process of strategic MIS planning with competitive strategy', Decision Sciences, 22(1): 953-984.

Day, G. S. 1994. 'The capabilities of market-driven organisations', Journal of Marketing, 58(4): 37-52.

Dean, J. \& Holmes, S.1997. 'Understanding business networks: Evidence from the manufacturing and service secures in Australia', Journal of Small Business Management, 35(1): 78-84.
Del Aguila-Obra, A.R. \& Padilla-Meléndez, A. 2006. 'Organizational factors affecting Internet technology adoption', Internet Research, 16(1): 94-110.

DeLone, W. 1988. 'Determinants of success for computer usage in small business', MIS Quarterly, 12(1): 51-61.

Dess, G. D. \& Robinson, R. B. 1984. 'Measuring organizational performance in the absence of objective measures: The case of the privately held firm and conglomerate business unit', Strategic Management Journal, 5(3): 265-273.

Doherty, N.F. \& Ellis-Chadwick, F, 2006. 'New perspectives in Internet retailing: A review and strategic critique of the field', International Journal of Retail and Distribution Management, 34(4/5): 411-428.

Durkin, M. \& McGowan, P. 2001. 'Net effect - views from the periphery: Exploring the role and importance of the internet on marketing activity in entrepreneurial firms', Irish Marketing Review, 14(1): 15-25.

Ettlie, J. E., Bridges, W. P. \& O'Keefe, R. D. 1984. 'Organization strategy and structural differences for radical versus incremental innovation', Management Science, 30(6): 682-695.

Evans, P. B. \& Wurster, T. S. 1997. 'Strategy and the new economics of information', Harvard Business Review, 75(5): 71-82.

Fahy, J. \& Smithee. A. 1999. 'Strategic marketing and the resource based view of the firm', Academy of Marketing Science Review, 10:1-20.

Feeny, D. F. \& Willcocks, L. P. 1998. 'Core IS Capabilities for exploiting information technology', Sloan Management Review, 39(3): 9-21.

Gilmore, A., Carson, D. \& Grant, K. 2001. 'SME marketing in practice', Market Intelligence and Planning, 19(1): 6-11.

Grant, R. M. 1991. 'The resource-based theory of competitive advantage: Implications for strategy formulation', California Management Review, 33(1): 114135 .

Gretzel, U., Yuan,Y-L. \& Fesenmaier, D. R. 2000. 'Preparing for the new economy: Advertising strategies and change in destination marketing organizations', Journal of Travel Research, 39(2): 146-156.

Hailey, J. 1992. 'Strategies for enterprise development: The policy implications', South African Journal of Entrepreneurship and Small Business, 4(2): 1-15.

Hair, J. F., Anderson, R. E., Tatham, R. L. \& Black, W. C. 1995. Multivariate data analysis: With readings. Englewood Cliffs, New Jersey: Prentice Hall. 
Hair, J. F., Anderson, R. E., Tatham, R. L. \& W. C. Black 1998. Multivariate data analysis. 5th Edition. Englewood Cliffs, New Jersey: Prentice Hall.

Haynes, P. J., Becherer, R. C. \& Helms, M. M. 1998. 'Small and mid-sized businesses and Internet use: Unrealised potential?' Internet Research: Electronic Networking Applications and Policy, 8(3): 229-235.

Hill, J. \& McGowan, P. 1996. 'Developing a networking competency for effective enterprise development', Journal of Small Business and Enterprise Development, 3(3): 14857.

Hoffman, D. L. \& Novak, T. P. 1997. 'A new marketing paradigm for electronic commerce', The Information Society, 13(1): 43-54.

Hoof, V., Hubert, B. C., Collins, R., Combrink, E. T. \& Verbeeten, J. M. 1995. 'Technology needs and perceptions: An assessment of the US lodging industry', Cornell Hotel and Restaurant Quarterly, 36(5): 64-70.

Hooley, G., Moller, K. \& Broderick, A. 1997. Competitive positioning and the resource-based view of the firm. Aston Business School Research Paper Series, RP9726.

Hunt, S. D. \& Morgan, R. M. 1995. 'The comparative advantage theory of competition', Journal of Marketing, 59(2): 1-15.

Hunt, S. D. \& Morgan, R. M. 1996. 'The resourceadvantage theory of competition: Dynamics, path dependencies, and evolutionary dimensions', Journal of Marketing, 60(3):107-114.

Jennrich, R. I. \& Sampson, P. F. 1996. 'Rotation for simple loadings', Psychometrika, 3(1): 313-323.

Jingting, L. \& Jinghua, H. 2004. 'An exploratory study of ebusiness success factors', Journal of Electronic Science and Technology of China, 2(3).

Jones, C., Hecker, R. \& Holland, P. 2003. 'Small firm Internet adoption: Opportunities forgone, a journey not begun', Journal of Small Business and Enterprise Development, 10(3): 287-297.

Jöreskog, K. G. \& Sörboom, D. 2003. LISREL: Version 8.5.4. Lincolnwood: Scientific Software Inc.

Kasavana, L. K., Knuston, B. J. \& Polonowski, S. J. 1997. 'Netlurking: The future of hospitality Internet marketing', Journal of Hospitality and Leisure Marketing, 5(1): 31-44.

Kickul, J. \& Walters, J. 2002. 'Recognizing new opportunities and innovations: The role of strategic orientation and proactivity in Internet firms', International Journal of Entrepreneurial Behaviour and Research, 8(6): 292-308.
Klein, S., Köhne, F. \& Öörni, A. 2004. 'Barriers to online booking of scheduled airline tickets', Journal of Travel and Tourism Marketing, 17(2/3): 27-39.

Kline, R. B. 1998. Principles and practices of structural equation modelling. Guildford Press: New York.

Kline, S. F., Morrison, A. M. \& John, A. S. 2004. 'Exploring bed and breakfast websites: A balanced scorecard approach', Journal of Travel and Tourism Marketing, 17(2/3): 253-267.

Lee, K. S., Tan, S. J. \& Lim, G. H. 2000. 'E-retailing: Success factors for entrepreneurial start ups'. Proceedings of the International Council for Small Business (ICSB) 2000 conference, 9 June 2000, Brisbane, Australia.

Lumpkin, G.T., Droege, S.B. \& Dess, G.G. 2002. 'Ecommerce strategies: Achieving sustainable competitive advantage and avoiding pitfalls', Organizational Dynamics, 39(4): 325-340.

Markham, S. K. \& Aiman-Smith, L. 2001. 'Product champions: Truths, myths and management', Research Technology Management, 44(3): 44-45.

Marshall, P., Sor, R. \& McKay, J. 2000. 'An industry case study of the impacts of electronic commerce on car dealerships in Western Australia', Journal of Electronic Commerce Research, 1(1): 1-16.

Martin, L. M. 2004. 'E-innovation: Internet impacts on small UK hospitality firms', International Journal of Contemporary Hospitality Management, 16(2): 82-90.

Mata, F. J., Fuerst, W. L. \& Barney, J. B. 1995. 'Information technology and sustained competitive advantage: A resource-based analysis', MIS Quarterly 19(4): 487-505.

McGowan, P. \& Durkin, M. 2002. 'Toward an understanding of Internet adoption at the marketing/entrepreneurship interface', Journal of Marketing Management, 18(3/4): 361-377.

McGowan, P., Durkin, M. L., Allen, C. D. \& Nixon, S. 2001. 'Developing competencies in the entrepreneurial small firm for use of the Internet in the management of customer relationships', Journal of European Industrial Training, 25(2/3/4):126-136.

Mehrtens, J., Cragg, P. B. \& Mills, A. M. 2001. 'A model of Internet adoption by SMEs', Information and Management, 39(3): 165-176.

Middleton, V. T. C. \& Clarke, J. R. 2001. Marketing in travel and tourism. 3th Edition. Oxford: ButterworthHeinemann.

Molla, A. \& Licker, P. S. 2001. 'E-commerce systems success: An attempt to extend and respecify the Delone and Maclean model of IS success', Journal of Electronic Commerce Research, 2(4): 131-141. 
Moore, G. C. \& Benbasat, I. 1991. 'Development of an instrument to measure the perceptions of adopting an information technology innovation', Information Systems Research, 2(3): 192-222.

Morrison, A., Lynch, P. \& Johns, N. 2004. 'International tourism networks', International Journal of Contemporary Hospitality Management, 16(3): 197-202.

Nicholls, A. \& Watson, A. 2005. 'Implementing e-value strategies in UK retailing', International Journal of Retail and Distribution Management, 33(6):426-443.

Nilson, T. H. 1992. Value-added marketing: Marketing management for superior results. London: McGraw-Hill.

Nunnally, J. C. \& Bernstein, I.H. 1994. Psychometric theory. New York: McGraw-Hill.

O'Connor, P. 2004. 'Conflicting viewpoints on Web design', Journal of Travel and Tourism Marketing, 17(2/3): 225-230.

O'Toole, T. 2003. 'E-relationships- emergence and small firms', Marketing Intelligence and Planning, 21(2): 115122.

Öörni, A. 2004. 'Consumer objectives and the amount of search in electronic travel and tourism markets', Journal of Travel and Tourism Marketing, 17(2/3): 3-14.

Palmer, A. 2001. Principles of services marketing. 3rd Edition. Glasgow: McGraw-Hill.

Palmer, A. \& McCole, P. 2000. 'The role of electronic commerce in creating virtual tourism destination marketing organisations', International Journal of Contemporary Hospitality Management, 12(3): 198-204.

Piercy, N. F. \& Cravens, D. W. 1995. 'The network paradigm and the marketing organisation: Developing a new management agenda', European Journal of Marketing, 29(3): 7-34.

Poon, S. \& Swatman, P. M. C. 1999. 'An exploratory study of small business Internet commerce issues', Information and Management, 35(1): 9-18.

Porter, M.E. 2001. 'Strategy and the Internet', Harvard Business Review, 79(3): 63-78.

Powell, T. C. \& Dent-Micallef, A. 1997. 'Information technology as competitive advantage: The role of human, business, and technology resources', Strategic Management Journal, 18(5): 375- 405.

Raykov, T., Tomer, A. \& Nesselroade, J. R. 1991. 'Reporting structural equation modelling results in psychology and aging: Some proposed guidelines', Psychology and Aging, 6, 499-503.

Rogers, E. M. 1995. Diffusion of innovations, 4th Edition. New York: Free Press.
Rogerson, C. M. 2002a. 'Driving developmental tourism in South Africa', Africa Insight, 32(3): 33-42.

Rogerson, C. M. 2002b. 'Tourism - A new economic driver for South Africa'. In Lemon, A. \& Rogerson, C. M. (Eds.). Geography and economy in South Africa and its neighbours. Aldershot: Ashgate. P.p. 95-110.

Rogerson, C. M. 2003. 'Tourism and transformation: Small enterprise development in South Africa', Africa Insight, 33(1/2): 108-115.

Ross, J. W., Beath, C. M. \& Goodhue, D. L. 1996. 'Develop long-term competitiveness through IT assets', Sloan Management Review, 38(1): 31-42.

Rust, R. 1999. 'Technology and service', Journal of Service Research, 1(3): 195.

Satorra, A. \& Bentler, P. M. 1994. 'Corrections to test statistics and standard errors in covariance structure analysis'. In Von Eye, A. \& Clogg, C. C. Eds. Latent variable analysis: Applications in developmental research. Newbury Park: Sage Publishing.

Shane, S. \& Venkataraman, S. 2000. 'The promise of entrepreneurship as a field of research', Academy of Management Review, 25(1): 217-26.

Sigala, M. 2004. 'Reviewing the profile and behaviour of Internet users: research directions and opportunities in tourism and hospitality', Journal of Travel and Tourism Marketing, 17(2/3): 93-102.

Stansfield, M. \& Grant, K. 2003. 'An investigation into issues influencing the use of the Internet and electronic commerce among small-medium sized enterprises', Journal of Electronic Commerce Research, 4(1): 15-33.

Stokes, D. 2000. 'Entrepreneurial marketing: A conceptualisation from qualitative research', Qualitative Market Research: An International Journal, 3(1): 47-54.

Teece, D. J., Pisano, G. \& Shuen A. 1997. 'Dynamic capabilities and strategic management', Strategic Management Journal 7 (18): 509-533.

Thong, J. \& Yap, C. S. 1995. 'CEO characteristics, organisational characteristics, and information technology adoption in small business', Omega, 23(4): 429-442.

Turban, E., J., King, D. L. \& Chung, H. M. 2000. Electronic commerce - A managerial perspective. Upper Saddle River, New Jersey: Prentice-Hall.

Turban, E. \& Gehrke, D. 2000. 'Determinants of ecommerce website', Human Systems Management, 19: 111120.

Venkatraman, N. \& Ramanujam, V. 1987. 'Measurement of business economic performance: An examination of method convergence', Journal of Management, 13(1): 109-122. 
Wade, M. \& Hulland, J. 2004. 'Review: The resource-based view and information systems research: Review, extension, and suggestions for future research. MIS Quarterly, 28(1): 107-142.

Walle, A. H. 1996. 'Tourism and the Internet: Opportunities for direct marketing', Journal of Travel Research, 35(1): 7277 .

Wernerfelt, B. 1984. 'A resource-based view of the firm', Strategic Management Journal, 5(2): 171-180.
Wu, F., Mahajan, V. \& Balasubramanian, S. 2003. 'An analysis of e-business adoption and its impact on business performance', Journal of the Academy of Marketing Science, 31(4): 425 -447.

Zhuang, Y. \& Lederer, A. L. 2006. 'A resource-based view of e-commerce', Information and Management, 43(1): 251261. 


\begin{tabular}{|c|c|}
\hline \multicolumn{2}{|c|}{ APPENDIX A } \\
\hline SUC9 & I am satisfied that the Internet enhances our customer service \\
\hline SUC10 & I am satisfied that the Internet assists us in conveying information about our business to customers \\
\hline SUC8 & I am satisfied that use of the Internet improves the effectiveness of advertising and promoting our business \\
\hline SUC7 & I am satisfied that use of the Internet improves the image of our business \\
\hline SUC5 & I am satisfied that use of the Internet for marketing assists us in getting repeat business \\
\hline SUC4 & I am satisfied that the Internet assists us in maintaining relationships with existing customers \\
\hline SUC6 & $\begin{array}{l}\text { I am satisfied that the Internet improves our ability to find out information about customers, competitors and the } \\
\text { tourism industry }\end{array}$ \\
\hline SUC3 & I am satisfied that our Web site assists us in getting referrals (word of mouth) \\
\hline TK4 & I understand enough about Internet marketing to make informed decisions \\
\hline TK3 & I am knowledgeable about the use of the Internet for marketing \\
\hline TK5 & I know what is required to make the Internet effective for marketing \\
\hline TK2 & I understand the issues surrounding the use of the Internet for marketing \\
\hline PC1 & I am excited about the use of the Internet for marketing our business \\
\hline PC2 & I am enthusiastic about the use of the Internet for marketing our business \\
\hline TK1 & I appreciate what the Internet can do for the marketing of our business \\
\hline PC3 & I am committed to using the Internet for marketing our business \\
\hline PC4 & I am passionate about using the Internet for marketing our business \\
\hline PC7 & I believe that the Internet can add value to the marketing of our business \\
\hline TK6 & I am aware of the potential of using the Internet for the marketing our business \\
\hline ALI3 & Our business associates improve our proficiency at obtaining information on how to market over the Internet. \\
\hline ALI4 & Our business associates' advice exerts an influence over the way our business markets over the Internet. \\
\hline ALI2 & We have strong associations with people who can assist us with advice on Internet marketing \\
\hline ALI5 & Informal networks are a source of information on Internet marketing \\
\hline
\end{tabular}


